\title{
UNDERSTANDING THE MANAGEMENT ORGANIZATION STRUCTURE OF PAPRIKA PRODUCTION AREAS IN INDONESIA BASED ON THE VIEWPOINT OF FORTHCOMING GLOBALIZATION
}

\author{
Ryohei Yamashita \& Ubaidillah Zuhdi \\ Department of Environmental Science, Ishikawa Prefectural University \\ Faculty of Economics and Business, Universitas Nahdlatul Ulama Surabaya \\ e-mail: r-yama@ishikawa-pu.ac.jp, ubaidillah.zuhdi@unusa.ac.id
}

\begin{abstract}
The purpose of this study was to understand the management structure that is developing based on social marketing style within the largest paprika-production areas in Indonesia. Through this research, we aimed to clarify the direction and challenges for future development using the strengths, weaknesses, opportunities, and threats (SWOT) analysis method. A field survey of local farming organizations was conducted on December 2011 at West Bandung Regency, Java, Indonesia. The results show that nearly the entire structure of the system was dedicated to the production and sale of raw paprika without creating any processed product. The counterparties were not corporations but individual buyers. Farming organizations could expand their counterparties to include corporations, but they do not use this strategy because they believe that the production speed of the mature laborers was not sufficient to keep up with market demands, and a rash judgment to expand the management scale would necessarily lead to the degradation of product quality. These farming organizations empirically understand that they could lose counterparties; therefore, they attach greater importance to maintaining faithful counterparties than to attracting new customers.
\end{abstract}

Keywords: social marketing, agricultural corporation, globalization, SWOT analysis

\section{INTRODUCTION}

The analytical discipline used in this research was social marketing proposed by Kotler and Zaltman (1971, 2008). Social marketing is the discipline of marketing and management that is compatible with the prosperity of the community in which a company is located and a sustainable development of the business with its trading partners. The continuous development of a rural community significantly contributes to the success of a company rooted within the region. In more detail, a developing rural community will provide the company with the ability to expand its business based on social marketing.

In East Asian countries such as Japan, domestic farming faces significant price competition resulting from the Trans-Pacific Strategic
Economic Partnership Agreement (TPP) trade agreement. Many countries surrounding the Pacific Ocean are currently part of TPP; therefore, it is important to study the status quo of and prospects for agricultural production in these countries. Under the circumstances, agriculture is not considered to be a growth industry in a shrinking domestic market; therefore, large-scale diversified management practices from small-scale management, a productioncost reduction by selecting and concentrating on management resources, and an income-increasing strategy by expanding exports have been promoted as new policy directives (Sekine and Bonanno, 2016). Apart from the new directives, small farming must be reevaluated (Hisano et al. 2018); however, there is a high possibility 
Table 1 Management Type Classifications in Agricultural Companies in Japan

\begin{tabular}{|c|c|c|l|}
\hline Type & $\begin{array}{c}\text { Interest in } \\
\text { Non- } \\
\text { Agribusiness }\end{array}$ & $\begin{array}{c}\text { Interest in } \\
\text { Overseas } \\
\text { Advance }\end{array}$ & \multicolumn{1}{c|}{$\begin{array}{c}\text { Other Features (Agricultural Companies } \\
\text { of this Type Are...) }\end{array}$} \\
\hline A & Very strong & Very strong & Very active in management expansion like a general company. \\
\hline B & Weak & Medium & $\begin{array}{l}\text { Believe that preservation of agricultural land in the area holds } \\
\text { maximum preference and give priority to goods' quality based } \\
\text { on the company's interests. }\end{array}$ \\
\hline C & Weak & Weak & $\begin{array}{l}\text { Act conservatively and have comparatively high sales volume. } \\
\text { Are interested in the dissolution of an abandoned cultivated } \\
\text { land and preservation of agricultural land in the area. Do not } \\
\text { recognize that the market mechanism is functioning in the } \\
\text { agricultural market in present-day Japan. Have sales scales that } \\
\text { are comparatively large. }\end{array}$ \\
\hline
\end{tabular}

Note: Based on Shinkai (2006)

that a shift to highly competitive, large-scale farming will continue.

In the context of examining the alternatives for achieving these directives, management of the evaluated agricultural companies must be considered. In this study, we attempted to understand management development using social marketing by comparing it with the Japanese corporate format about agriculture.

Regarding the Japanese agricultural company types, Shinkai (2006) has identified the different management strategies and has divided them into four types using cluster analysis and the results obtained from an interview with the company administrators; however, we have reclassified these into three types (Table 1 ) by combining two similar categories from Shinkai's model. The company under analysis here is the most similar to type B. It is difficult for a typeB company to maintain dominance in the Japanese domestic market because of the high costs related to personnel or low prices of its agricultural products.

Using linear programming, Higuchi and Munandar (1999) have proposed the optimal planting plan for a paddy field. Fujita (1990) have analyzed the structure of the labor force and worker productivity in conventional farming prac- tices for paddy rice and two or more other crops in Kecamatan Cisarua, Indonesia; however, there are few studies that have compared the conditions between areas of fruit and vegetable production in Japan and Indonesia. Since 1990, only Asami (1997), Kobayashi (1995), and Higuchi et al. (2001) have conducted studies that have analyzed agricultural systems and the organizational structures of the fruit and vegetable production areas that have sustained stable growth.

In recent years, the main concern over Indonesia's agricultural market has shifted from local paddy farming to mass distribution of fruit and vegetable, which indicates that the traditional market in the area has become inferior to modern supermarkets (Tumbuan et al., 2006). Our current study concentrated on a company that has no wholesale practices with large-scale companies, such as supermarkets, and has increased the size of its business through individual relationships with small or middle size customers within Indonesia. Interestingly, the reviewed company that puts a high value on customer reliance and maintains cooperative relationships with familiar customers has responded differently to these conditions.

The purpose of this paper is twofold. First one is to understand the difference in the man- 
agement structure of Indonesia's agricultural production areas with respect to a typical Japanese agricultural company. Second one is to considers a growth strategy for Indonesia's agricultural production areas based on the dynamics of global agricultural trade. In rural areas, agricultural production activities are integrated into the citizens' social life; therefore, comparing the features of farming in the context of rural planning is very important from both an academic and a practical perspective. Previous Japanese studies have conducted observational and analytical research on paddy field management in Indonesia. For example, Takada et al. (2004) have surveyed the trend of productivity and profits from organic paddy rice.

PRELIMINARY CONSIDERATION OF AGRICULTURAL SECTORS OF INDONESIA AND JAPAN

Our study used input-output (IO) analyses to compare the agricultural sectors within Indonesia and Japan. Indonesian sectors were analyzed from 2005 through 2010; Japanese sectors were analyzed from 2005 through 2011. The data sources for Indonesia were BPS-Statistics Indonesia, 2015 and 2016. The data sources for Japan were the Japanese Ministry of Internal Affairs and Communications, 2009 and 2016. The detailed information for both countries is provided in Figures 1-4 and Tables 2-4.

\section{The Case of Indonesia}

Tables 2 and 3 show the industrial sectors in Indonesia that were used in this study for 2005 and 2010, respectively. Nine industries were evaluated in 2005 and 17 in 2010 . Sector 1 represents Indonesia's agricultural sector.
The first step is to explain the following methods used: 1) the index of the power of dispersion and 2) the index of the sensitivity of dispersion. Both methods are devices for IO

Table 2 Industrial Sectors in Indonesia in 2005

\begin{tabular}{|c|l|}
\hline $\begin{array}{c}\text { Sector } \\
\text { Number }\end{array}$ & \multicolumn{1}{|c|}{ Sector Name } \\
\hline 1 & Agriculture, livestock, forestry, and fishery \\
\hline 2 & Mining and quarrying \\
\hline 3 & Manufacturing industry \\
\hline 4 & Electricity, gas, and water supply \\
\hline 5 & Construction \\
\hline 6 & Trade, hotel, and restaurant \\
\hline 7 & Transport and communication \\
\hline 8 & Financial, real estate, and business services \\
\hline 9 & Services \\
\hline
\end{tabular}

Source: Zuhdi (2016)

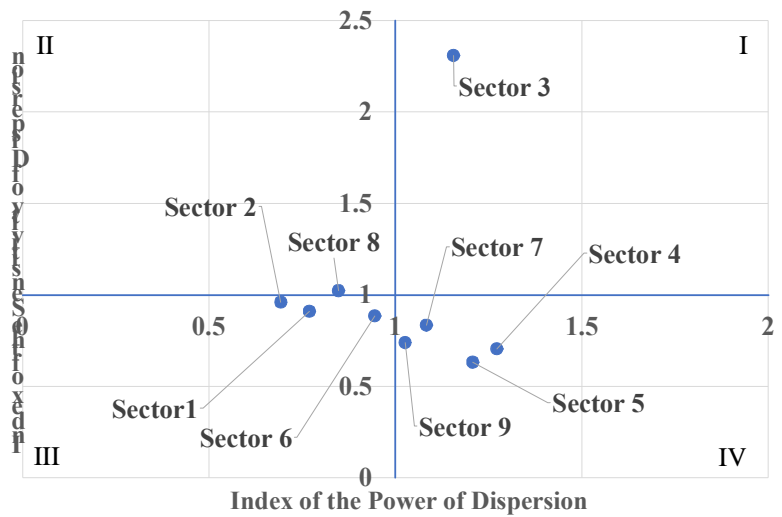

Figure 1 Quadrants of the Industrial Sectors in Indonesia in 2005

Source: Zuhdi (2016)

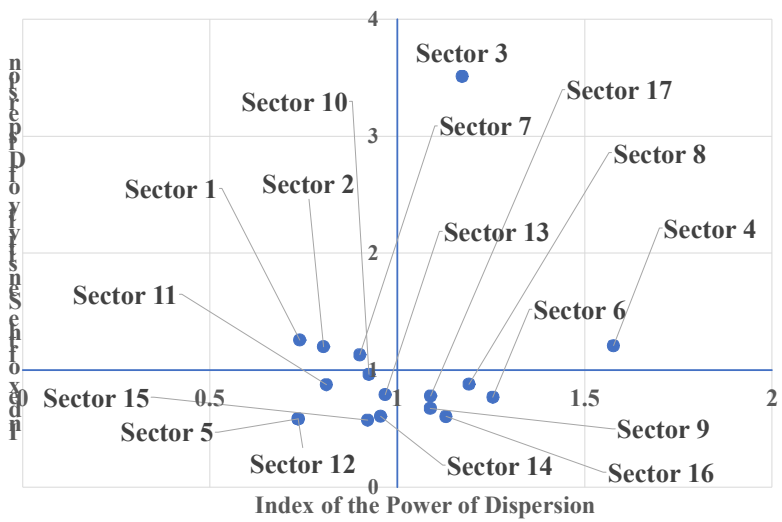

Figure 2 Quadrants of the Industrial Sectors in Indonesia in $\mathbf{2 0 1 0}$ Source: Zuhdi (2017a) 
Table 3 Industrial Sectors in Indonesia in 2010

\begin{tabular}{|c|l|}
\hline $\begin{array}{c}\text { Sector } \\
\text { Number }\end{array}$ & \multicolumn{1}{c|}{ Sector Name } \\
\hline 1 & Agriculture, forestry, and fishing \\
\hline 2 & Mining and quarrying \\
\hline 3 & Manufacturing \\
\hline 4 & Electricity and gas \\
\hline 5 & $\begin{array}{l}\text { Water supply, sewerage, waste management, } \\
\text { and remediation activities }\end{array}$ \\
\hline 6 & Construction \\
\hline 7 & $\begin{array}{l}\text { Wholesale and retail trade; repair of motor } \\
\text { vehicles and motorcycles }\end{array}$ \\
\hline 8 & Transportation and storage \\
\hline 9 & Accommodation and food service activities \\
\hline 10 & Information and communication \\
\hline 11 & Financial and insurance activities \\
\hline 12 & Real estate activities \\
\hline 13 & Business activities \\
\hline 14 & $\begin{array}{l}\text { Public administration and defense; compulsory } \\
\text { social security }\end{array}$ \\
\hline 15 & Education \\
\hline 16 & Human health and social work activities \\
\hline 17 & Other services activities \\
\hline
\end{tabular}

Source: Zuhdi (2017a)

analyses. The second step is to provide detailed information about both indices. The first index is applied to analyze the strength of one specific sector in influencing the entire industry. A higher index value represents a stronger influence. Detailed information regarding the index was provided by the Japanese Ministry of Internal Affairs and Communications (n.d.) as follows:

Index of the power of dispersion by sector

$$
=\frac{b * j}{\bar{B}}
$$

where the numerator is the column sum in the table of inverse matrix coefficients and the denominator is the mean value of the column sum. These calculations are explained as follows:

$$
\begin{aligned}
& b_{*_{j}}=\sum_{i}^{n} b_{i j} \\
& \bar{B}=\frac{1}{n} \sum_{i} b_{i^{*}}=\frac{1}{n} \sum_{i} \sum_{j} b_{i j}
\end{aligned}
$$

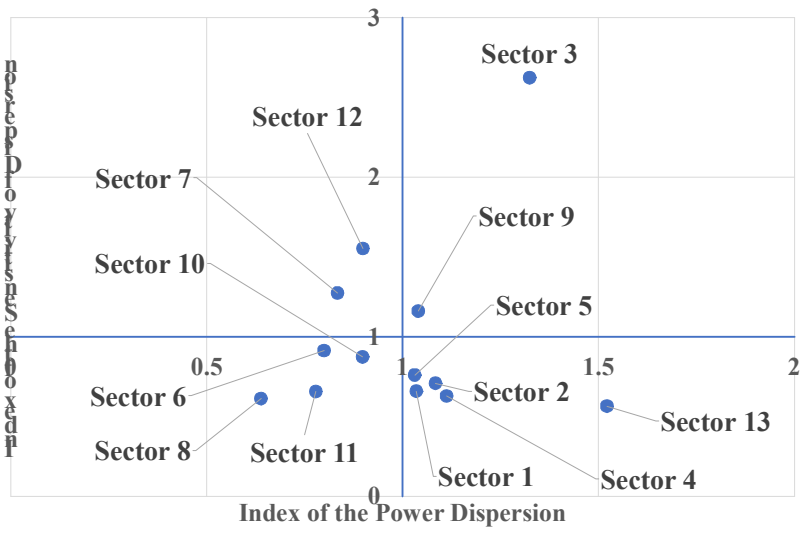

Figure 3 Quadrants of the Industrial sectors in Japan in 2005

Source: Zuhdi (2017b)

where bij and $\mathrm{n}$ are the Leontief inverse value from sector $\mathrm{i}$ to sector $\mathrm{j}$, and total number of analyzed industries, respectively.

The second index was applied to analyze the sensitivity of the specific sector to external influences. A higher index value represents greater sensitivity. More specifically, one particular sector with an index value greater than that of the others is identified as being more sensitive to external influences. The detailed information regarding the index was provided by the Japanese Ministry of Internal Affairs and Communications (n.d.) as follows:

Index of the sensitivity of dispersion by sector

$$
=\frac{b_{i^{*}}}{\bar{B}}
$$

The numerator is the sum of the row in the table of inverse matrix coefficients; the denominator is the mean value of the entire horizontal sum. The numerator and denominator were calculated as follows:

$$
\begin{aligned}
& b_{i^{*}}=\sum_{j}^{n} b_{i j} \\
& \bar{B}=\frac{1}{n} \sum_{i} b_{i^{*}}=\frac{1}{n} \sum_{i} \sum_{j} b_{i j}
\end{aligned}
$$


To be compatible with the previous index, Eq. (5) was slightly modified from the original. More specifically, the total number of discussed industries, $\mathrm{n}$, is added into the equation. As with the previous explanation, bij is the Leontief inverse value from sector $\mathrm{i}$ to sector $\mathrm{j}$. The final step is to perform the calculations using both indices.

Figures 1 and 2 describe the positions of the industrial sectors in Indonesia using four quadrants, each with specific characteristics, for 2005 and 2010, respectively. According to Zuhdi (2017b), the industrial sectors in quadrant I have strong influences on the entire industry and are most affected by external influences. The opposite is true for those in quadrant III. On the other hand, the industrial sectors in quadrant II have weak impacts on the entire industry but are highly affected by the dynamics of external influences. The opposite is true for the sectors in quadrant IV. Based on the information in Figures 1 and 2, we observed that Indonesian sector 1 moved from quadrant III to quadrant II within the analysis period.

Table 4 Industrial Sectors in Japan in 2005 and 2011

\begin{tabular}{|c|l|}
\hline $\begin{array}{c}\text { Sector } \\
\text { Number }\end{array}$ & \multicolumn{1}{|c|}{ Sector Name } \\
\hline 1 & Agriculture, forestry, and fishery \\
\hline 2 & Mining \\
\hline 3 & Manufacturing \\
\hline 4 & Construction \\
\hline 5 & Electricity, gas, and water supply \\
\hline 6 & Commerce \\
\hline 7 & Finance and insurance \\
\hline 8 & Real estate \\
\hline 9 & Transport and postal services (For 2005: \\
\hline 10 & Transport) \\
\hline 11 & Information and communications \\
\hline 12 & Pervices \\
\hline 13 & Activities not elsewhere classified \\
\hline
\end{tabular}

Source: Zuhdi (2017b)

\section{The Case of Japan}

Table 4 provides a breakdown of the industrial sectors within Japan in 2005 and 2011 that were used in this study. The main difference among the industrial sectors is that the name for sector 9 changed from "Transport" in 2015 to "Transport and postal services" in 2011. There were 13 industries evaluated in this analysis. The agricultural sectors in Japan are designated as sector 1 . The calculation method used for Indonesia is also used for Japan.

Figures 3 and 4 provide the positions of the industrial sectors within Japan separated into four quadrants for 2005 and 2011, respectively. These results suggest that sector $1 \mathrm{did}$ not move among the quadrants during the analysis period.

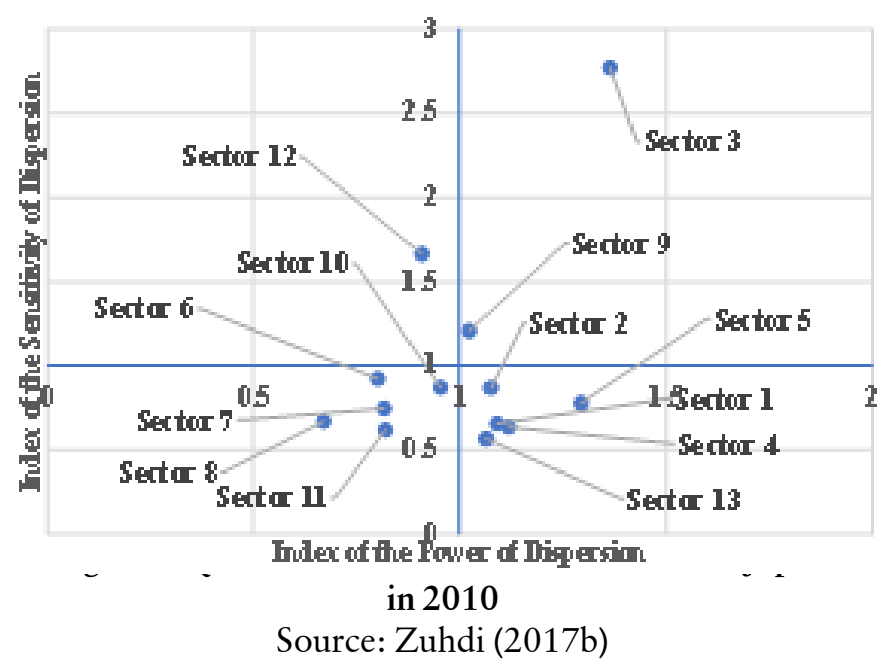

We then focused more intensely on Indonesia because, based on previous explanations, the Indonesian agricultural sector moved from one quadrant to another during the analysis period. This movement indicated that the role of the sector on the Indonesian economy had shifted in a positive direction during the study. 


\section{STUDY AREA}

This study analyzes M-Co., a large company within Pasirlangu village, Cisarua subdistrict, West Bandung district (-6.7978371 S,107. $5301628 \mathrm{E}$ ), that operates within the paprika market using large-scale agricultural land. The area is located in the mountainous region of the West Java, situated in Midwest Java Island (Figure 5). Pasirlangu village is a mountainous agricultural region located $2-3 \mathrm{~h}$ by car from Bandung. The pathway leading to the village from urban areas is a continuous, uneven dirt road along the valley (Figure 6).

\section{Basic Management Philosophy}

The M-Co was chosen as the target company for analysis. Interviews were conducted with the company's accountant (Bendahara), Mr. E, who was 42 years old. According to Mr. E's responses, M-Co. was founded in 1995 as a private organization and has grown into a licensed company that has consistently employing local farmers. Once M-Co. attempted to produce ketchup by processing raw paprika, but the plan was derailed by the high production cost. After that, MCo. has cultivated only paprika and sold only nonprocessed paprika since its inception.
Although there are reports that supermarkets are inferior because of sales along the streets. (Suryadarma et al. 2010), the demand for the supermarket which is a more modern sales form seems to be high, especially in the urban suburban area. However, nearly all of its trading partners have been individual wholesalers who have traded with the company for several years. M-Co. does not trade with other large-scale companies, such as supermarkets, in the domestic market to avoid being marginalized as much as possible. In addition, whether intermediate wholesalers trading with M-Co. also deal with the major traders was unconfirmed by the survey, although M-Co. does not do so directly; however, the buyer or seller usually must transport goods from the store in the mountainous area to urban areas by bicycle after the transactions. Thus, a buyer who wholesales a large amount of fresh merchandise to a large store, such as supermarkets and hotels, is rare because the amount that can be traded and transported at any one time is limited.

Because the rate of domestic business is $\sim 70 \%$ of the total transaction volume, M-Co. was a domestic-minded company. Although the number of transactions differed mainly because of an increase in the number of local custom-

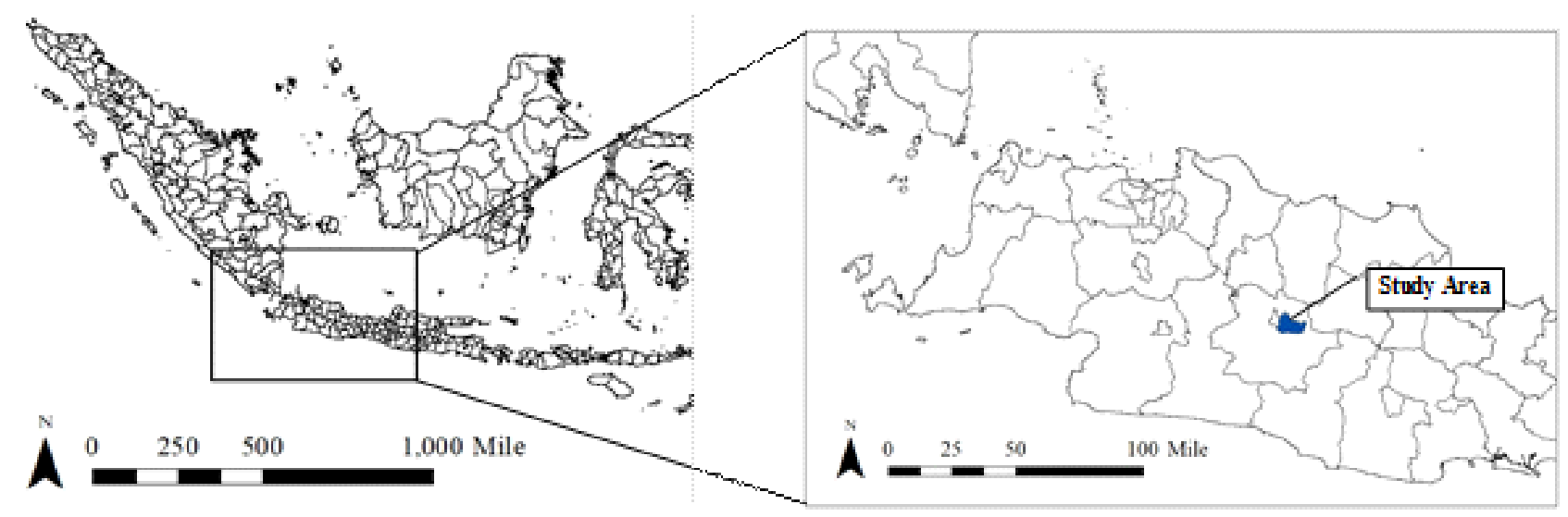

Figure 5 Landscape from Uneven Dirt Road to the Village Source: Photo by Yamashita R. 
ers, which had increased by $5 \%$ annually because of the company's positive reputation, the company did not change its price/unit of paprika (Table 5). The reason for fixing the wholesale price was the belief that if the wholesale price were to be changed through negotiations with individual customers, it would damage the company's credibility, which it had realized over a long period of time.

Approximately 6-7 t paprika is exported each week and, if domestically traded, the company incurs the total transportation cost. According to the interview in this study, the annual gross income, including earnings and government subsidies, is approximately twice the annual cost, including the cost of transportation and labor.

Table 5 Wholesale Price of Paprika (per kg)

\begin{tabular}{|l|c|c|}
\hline Variety (Color) & High Quality & Low Quality \\
\hline Yellow & 45,000 rupiahs & 16,000 rupiahs \\
\hline Red & 40,000 rupiahs & 15,000 rupiahs \\
\hline Green & 20,000 rupiahs & 10,000 rupiahs \\
\hline
\end{tabular}

Source: Interview record with the company's accountants

\section{Factors to ensure current competitive ad- vantage}

Based on M-Co.'s management philosophy, the elements of competitiveness within the region are specifically organized. Because M-Co. has a system in which individual production performance is reflected in salary, the employees are motivated to improve their cultivation methods. In addition, if there are doubts and requests concerning cultivation methods, a special extension worker is dispatched from the government to provide guidance. Moreover, although all employee's a salary is based on individual accomplishment, each employee of

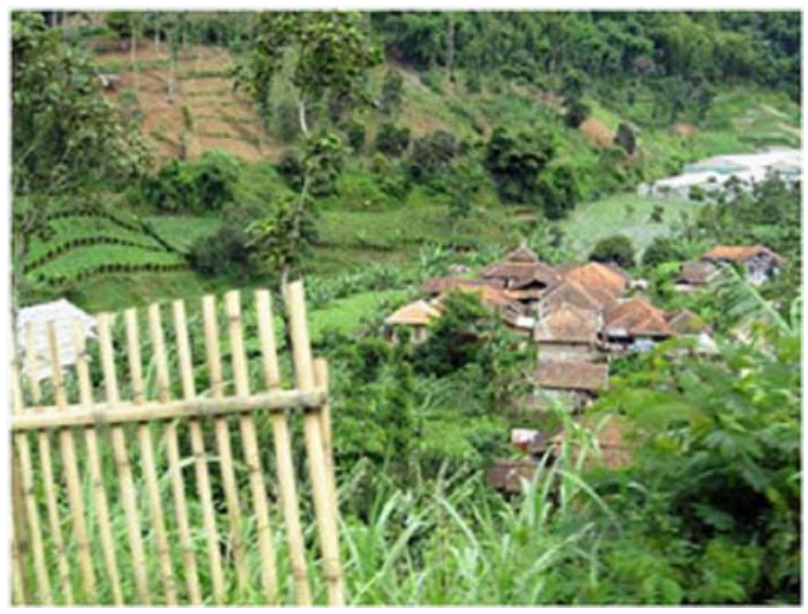

Figure 6 Study Area on Java

M-Co. shares his or her methods of success and agricultural know-how. According to this interview to M-Co., the employees of the competing neighboring company have worked under the same salary systems and have similar mind. This is because the farmers of the area share the social norm of reciprocity that only their own affiliated company should not be successful. M-Co. emphasizes client relationships with a focus on mutual trust.

Based on its experience that most customers rely on mutual trust about prompt and accurate commodity supply to them rather than excessive advertising of their commodity with uncertainty, M-Co does not accept orders that exceed its supply capacity. In addition, M-Co. accepts orders from new customers only after ensuring that the needs of existing customers have been met, thereby placing less emphasis on maximizing profit. The company also considers that the cumulative knowledge and skills with respect to cultivation management are a priority and deems them crucial for maintaining the quality of the commodities.

In addition, despite little land and labor constraints, M-Co. have not scaled up to meet market needs. The reason is that it emphasizes 
the ability development of employees to maintain the quality demanded by customers, and has a rule of thumb that the quality cannot be maintained if the scale is expanded blindly. Therefore, when $\mathrm{M}$-Co. receives large requests from new suppliers, it has carefully scrutinized them in order to maximize long-term profits.

Considering the above management discipline, we observed that M-Co. balanced a competitive superiority in market share with the stable development within the community. That is, it can be considered an example of a company that has been successful through social marketing.

ANALYSIS OF THE STRENGTHS, WEAKNESSES, OPPORTUNITIES, AND THREATS OF THE COMPANY'S STANDING POSITION

Social marketing, anticipated to be a method by which a company has stable development within the community, was not based on a rational allocation of resources by selection and concentration. Thus, whether a business based on social marketing would continue to be dominant in future market competition is of interest.

We examined the future of agricultural production in Indonesia from the viewpoint of the internationalization of the agricultural product market by systematizing fragmented information gathered in a field survey about management strategy and the principles and methods of maintaining client relationships following a logical framework using an analysis of the strengths, weaknesses, opportunities, and threats (SWOT). A SWOT analysis allows for strategy formulation based on a matrix of the company's business condition that comprises internal (strength and weakness) and external factors (opportunity and threat).

Table 6 presents the results of the SWOT analysis conducted for M-Co. It was presumed that there were two internal factors affecting the company's marketing strategy. The first is that "M-Co. intends to develop domestically" and the second is that "M-Co. intends to develop globally". The SWOT characteristic "opportunity" (external factor) is a population increase in Indonesia or a neighboring country that would lead to an increase in the number of consumers. Moreover, the farming village offers superior climatic conditions for paprika cultivation, coloring, and taste. On the other hand, "threat" is the risk that efficient workers will exit from the agricultural industry because of the declining attraction to the industry considering urbanization and industrialization in Indonesia

Next, the study hypothesized that M-Co.'s "strengths" were its intentions for domestic development, which are popular in the domestic market, and its dependence on loyal, valued customers.

On the other hand, it hypothesizes that its main "weakness" was the social norm of reciprocity in the area that only M-Co.'s affiliated company should be unsuccessful, which can delay the company's growth. Moreover, MCo.'s strengths in the virtual market were its forward view of global development with the intension of worldwide competitiveness. This is because the area has surplus land and labor force on which M-Co. can capitalize. On the other hand, the company's weakness was that this scenario is associated with a risk of a decrease and the loss of trust from domestic customers and stable trade with existing customers in exchange for increased customer vol- 
Ryohei Yamashita \& Ubaidillah Zuhdi, Understanding the Management Organization Structure of Paprika Production Areas in Indonesia Based on the Viewpoint of Forthcoming Globalization

Table 6 SWOT Analysis of Management Deployment in M-Co.

\begin{tabular}{|c|c|c|}
\hline & $\begin{array}{c}\text { Opportunity } \\
\text { - Consumer expansion due to an } \\
\text { increase in domestic and neighboring } \\
\text { country population } \\
\text { - Optimal climate conditions for } \\
\text { paprika cultivation } \\
\end{array}$ & $\begin{array}{l}\text { Threat } \\
\text { - Reduction of agriculture by } \\
\text { urbanization (wages lower than those } \\
\text { in other industries) }\end{array}$ \\
\hline $\begin{array}{l}\text { Strength: Orientation toward } \\
\text { domestic development } \\
\text { - Most popular in domestic market } \\
\text { - Loyal, valued customers }\end{array}$ & $\begin{array}{l}\text { Strategy for gaining an advantage } \\
\text { using one's strength } \\
\text { Maintenance or expansion of a sales } \\
\text { channel in an individual company } \\
\text { and pursuance of high-quality goods }\end{array}$ & $\begin{array}{l}\text { Strategy for avoiding a threat using } \\
\text { one's strength } \\
\text { Securing employment costs by new } \\
\text { business developments and getting } \\
\text { new large-scale purchases including a } \\
\text { company }\end{array}$ \\
\hline $\begin{array}{l}\text { Weakness: Orientation toward } \\
\text { domestic development } \\
\text { - Impossible to respond to a rapidly } \\
\text { growing customer base. } \\
\text { - Social norm of "Reciprocity" }\end{array}$ & $\begin{array}{c}\text { Strategy for overcoming a weakness } \\
\text { using a good opportunity } \\
\text { Management plan for steady } \\
\text { development and cooperation with } \\
\text { other companies } \\
\end{array}$ & $\begin{array}{l}\text { Assumed crisis in management } \\
\text { Shrinking of management scale by } \\
\text { workers' runoff to the urban area }\end{array}$ \\
\hline $\begin{array}{c}\text { Strength: Orientation toward global } \\
\text { deployment } \\
\text { - Sufficient land for management } \\
\text { expansion }\end{array}$ & $\begin{array}{l}\text { Strategy for gaining an advantage } \\
\text { using one's strength } \\
\text { Shift of management principle from } \\
\text { trust-based trade in Indonesia to } \\
\text { profit-maximization trade targeting } \\
\text { global markets } \\
\end{array}$ & $\begin{array}{l}\text { Strategy for avoiding a threat using } \\
\text { one's strength } \\
\text { Sharing the employment costs by } \\
\text { investing in a new large buyer } \\
\text { including a company }\end{array}$ \\
\hline $\begin{array}{c}\text { Weakness: Orientation toward } \\
\text { global deployment } \\
\text { - Loss of trust with domestic } \\
\text { customers }\end{array}$ & $\begin{array}{l}\text { Strategy of conquering a weakness } \\
\text { using a good opportunity } \\
\text { Improvement in the sales unit price } \\
\text { by heightening added value }\end{array}$ & $\begin{array}{l}\text { Assumed crisis in management } \\
\text { Weakening agricultural production } \\
\text { area by poor business performance }\end{array}$ \\
\hline
\end{tabular}

umes in foreign countries. The results of the SWOT analysis show that M-Co. could adopt the following strategies.

If M-Co. were to act with the intention of domestic market development, three issues would be of concern. First, the improved earnings resulting from new customers or breed improvement of paprika would need to be considered. Second, the reduction in production costs and increase in workers' wages to accommodate new customers, not only individual suppliers but also large-scale companies, to be competitive with other urban companies would need to be addressed. M-Co. could also follow a coalition or consolidation strategy with another company to cater to increasing customer demands following a merger with another company. Furthermore, if $\mathrm{M}$-Co. were unable to adapt to shifts in trends in the global fruit and vegetable markets, it could lose its competitiveness because of a shrinking management scale. The influence of weakness on M-Co.'s management is not as serious or apparent as the company's opportunity and strengths.

If M-Co. intends to develop with a focus on globalization, it must consider a strategy for acquiring a new large-scale buyer (a company) to cover potential employment costs; however, this strategy comes with the risk of a tradeoff between earning volume and the loss of domestic customers, which would have repercussions with respect to mutual trust. To overcome this weakness, the company could effectively implement a market strategy to promote the added value; however, M-Co. has neither the technology and experience nor the institution for realizing such a strategy. Therefore, it must make considerable investment and management re- 
forms. As a result, it might be more effective to shift its business contacts to a company both within and outside of Indonesia, which would allow the internationalization of the market to rapidly progress; however, there is a risk to this strategy in that if M-Co. loses its domestic and stable customers as a result of adopting such a plan, it would be difficult to recover those customers because of a lack of know-how and experience to deal with such a situation.

\section{CONCLUSIONS}

This study was conducted to clarify the management organizational structure of the largest paprika-production areas in Indonesia, to study the relationships among the organizations, and to analyze paprika production and the market. Based on the previous study, the role that the agricultural sector in Indonesia has on the Indonesian economy has shifted positively from 2005 through 2011. When a company shifts to profitoriented strategies, according to the experiential knowledge of the interviewee in this research, "a customer supports the ability to supply quality goods at a stable rate," and there is the possibility that a company might lose existing domestic customers if this company shift the discipline of management.

Social marketing is an important approach to stable development while avoiding excessive competition awareness within rural communities. However, it is difficult today to maintain the resilience of a company in current market environment robustly because of too much dependence on its mutual trust with customers. Therefore, given dynamic market conditions, companies must be wary and prepare to make appropriate management decisions and adopt suitable strategies.
Finally, future work on the remaining issues should be conducted. This study is an analysis of the competitive advantage among many types of companies, and market competition throughout Indonesia or within the state ranges has not been investigated. As a result, how much advances in competition a company which expand based on the discipline of social marketing such as M-Co. has not been objectively and statistically discussed. Additional studies to complement the information on these points are needed.

Internationalization of agricultural commodity trading, which will be involved in East Asia's agricultural production areas soon, is expected to look for rapid changes in past management philosophy, distribution range, and changes to management areas. For example, in Japan, it was decided that a direct payment to paddy farmers as income compensation would be abolished in 2018. In response, large-scale farmers are considering some countermeasures to this program; however, there is a high possibility that not all farmers can respond flexibly. As a result, it is possible for many farmers to continue to farm. On the other hand, it is uncertain whether the management philosophy of social marketing promoted by agricultural enterprises in Malaysia is effective in international competition; therefore, by conducting consumer behavior and intention surveys, the effectiveness of the conventional management philosophy can be inferred in more detail.

Additional investigations into more cases are required to more closely substantiate the concerns expressed in the above summaries. To compensate for the lack of data in this study, it is possible to compare the relative agricultural management of both countries and to examine the future prospects. 
Ryohei Yamashita \& Ubaidillah Zuhdi, Understanding the Management Organization Structure of Paprika Production Areas in Indonesia Based on the Viewpoint of Forthcoming Globalization

\section{ACKNOWLEDGEMENTS}

Authors would like to thank all the collaborators involved in this research for their valuable work. This study was funded by The Japan Society for the Promotion of Science (JSPS) KAKENHI (Grant Numbers 18K05864, and $16 \mathrm{H} 03311)$.

\section{REFERENCES}

Asami, A. 1997. Indonesia no Nousanbutsu Ryutsu (in Japanese). Nogyo to Keizai, Vol. 63, pp 86-93.

Fujita, K. 1990. Jawatou ni Okeru Roudoukankou ni Kansuru Itikousatsu: Seibu Jawasyu Tensuidentiiki no Nousontyousa kara (in Japanese). The Quarterly Journal of Agricultural Economy, Vol. 44, pp 1-53.

Higuchi, A. and Munandar, F., 1999. Farm Planning of Paddy Fields in Indonesia: Comparative Analysis of East Java and North Sumatra (in Japanese). Japanese Journal of Farm Management, Vol. 37, pp 113-118.

Higuchi, A., Kagawa, B., and Munandar, F., 2001. Farm Planning of Upland Fields in Indonesia (in Japanese). Japanese Journal of Farm Management, Vol. 39, pp 161-166.

Hisano, S., Akitsu, M., and McGreevy, S.R. 2018. Revitalising Rurality Under the Neoliberal Transformation of Agriculture: Experiences of Re-agrarianisation in Japan. Journal of Rural Studies, Vol. 61, pp 290-301.

Kobayashi, K. 1995. Hyohen Suru Nousanbutsu Ryutsu System-Oroshiuri Shijo no Kokusaihikaku (in Japanese), Nobunkyo.

Kotler, P. and Lee, N.R. 2008. Social Marketing: Influencing Behaviors for Good, 3rd edition. New York: SAGE Publications.
Kotler, P. and Zaltman, G. 1971. Social Marketing: An Approach to Planned Social Change. Journal of Marketing, Vol. 35, No. 3, pp 3-12.

Sekine, K. and Bonanno, A. 2016. The Contradictions of Neoliberal Agri-food: Corporations, Resistance, and Disasters in Japan. West Virginia: West Virginia University Press.

Shinkai, S., 2006. Emerging Business-oriented Farms and Farm Management Theories in Japan. Japanese Journal of Farm Management, Vol. 45, No. 4, pp 12-21.

Suryadarma, D., et al. 2010. Traditional Food Traders in Developing Countries and Competition from Supermarkets: Evidence from Indonesia. Food Policy, Vol. 35, pp 79-86.

Takada, N., Iwamoto, N., and Ohga, K., 2004. Organic Farming Movement in Central Java. Japanese Journal of Tropical Agriculture, Vol. 48, pp 270-273.

Tumbuan, A.W.J.F., Kawet, L., and Shiratake, Y. 2006. Significance of Traditional Market and Supermarket Functions for Local Farmers and Consumers: A Case Study on Marketing of Vegetables in Manado, North Sulawesi, Indonesia. Bulletin of the Faculty of Agriculture, Saga University, Vol. 92, pp 79-94.

Zuhdi, U. 2016. The Indonesian Economy in 2005: An Analysis Using the Input-Output Approach. Proceedings of 20th EBES Conference-Vienna, Vol. 3, pp 1825-1842.

Zuhdi, U., 2017a. An Analysis of the Characteristics of Indonesian Industrial Sectors: $2005-$ 2010. IOP Conference Series: Earth and Environmental Science, Vol. 88 (012026).

Zuhdi, U., 2017b. An Analysis of the Characteristics of Japanese Industrial Sectors 
from 2005 through 2011. IOP Conference Series: Earth and Environmental Science, Vol. 88 (012027).

www.bps.go.id accessed on 30 December 2016. www.bps.go.id accessed on 30 March 2017. www.soumu.go.jp accessed on 26 April 2016. www.soumu.go.jp accessed on 30 December 2016.

www.soumu.go.jp accessed on 30 March 2017. 